\title{
PHYTASE ENZYME IN DIETS CONTAINING DEFATTED RICE BRAN FOR GROWING SWINE
}

\author{
José Aparecido Moreira ${ }^{1}$; Dorinha Miriam Silber Schmidt Vitti ${ }^{1 *}$; Messias Alves da Trindade \\ Neto $^{2}$; João Batista Lopes ${ }^{3}$ \\ ${ }^{1}$ USP/CENA - Lab. de Nutrição Animal - C.P. 96 - 13400-970 - Piracicaba, SP - Brasil. \\ ${ }^{2}$ USP/FMVZ - Depto. de Nutrição e Produção Animal, Campus de Pirassununga, Av. Duque de Caxias Norte, 225 - \\ 13630-000 - Pirassununga, SP - Brasil. \\ ${ }^{3}$ UFPI - Centro de Ciências Agrárias, Campus Universitário de Socopo - 64049-550 - Teresina, PI - Brasil. \\ *Corresponding author <dovitti@cena.usp.br>
}

\begin{abstract}
Organic phosphorus is poorly utilized by monogastric animals because they lack phytase, the enzyme that cleaves the ortho-phosphate groups from the phytate molecule. Diets fed to pigs are supplemented with inorganic $P$, and this can increase environmental pollution and diet costs. Sixty mixed sex, half-breed pigs, were used to evaluate the effect of increasing dietary levels of phytase $\left(253,759,1265\right.$ and $1748 \mathrm{PU} \mathrm{kg}^{-1}$ feed) on animal performance as compared to a control without phytase but supplemented with dicalcium phosphate. Enzyme levels did not affect daily feed intake, food conversion, average daily weight gain, plasma $\mathrm{P}$ and $\mathrm{Ca}$, calcium and phosphorus in bone ash, and the calcium/phosphorus ratio in the plasma and bones. $\mathrm{A}$ quadratic relationship between phytase levels and the percentages of $\mathrm{P}$ and $\mathrm{Ca}$ in bone ash was observed, reaching a maximum at the 880 and 879 PU levels, respectively. Animals fed diets containing phytase presented low plasma $\mathrm{P}$ values when compared to the control, but no effects were observed for the regression analysis. Using $759 \mathrm{PU}$ phytase in rations containing corn, soybean bran and defatted rice bran for growing pigs can eliminate the use of traditional sources of $\mathrm{P}$.

Key words: environmental pollution, nutrition, performance, phosphorus, phytate
\end{abstract}

\section{ENZIMA FITASE EM DIETAS COM FARELO DE ARROZ DESENGORDURADO PARA SUÍNOS EM CRESCIMENTO}

\begin{abstract}
RESUMO: Os animais monogástricos não aproveitam eficientemente o $\mathrm{P}$ orgânico das dietas, pois não sintetizam a enzima fitase, sendo necessária a suplementação das rações com $\mathrm{P}$ inorgânico, podendo elevar o custo das dietas e a poluição ambiental. Foram utilizados 60 leitões mestiços (machos castrados e fêmeas) para avaliar a eficácia dos níveis dietéticos crescentes da enzima fitase $\left(253,759,1265\right.$ e $1748 \mathrm{UF} \mathrm{kg}^{-1}$ de ração) sobre os parâmetros de desempenho e comparar com o tratamento testemunha que diferia dos demais por não conter fitase e por conter fosfato bicálcico. Os níveis da enzima fitase não afetaram o consumo diário de ração, conversão alimentar, ganho diário de peso, $\mathrm{P}$ e Ca no plasma, cinzas no osso e relação cálcio e fósforo no plasma e osso. Observou-se relação quadrática entre os níveis dietéticos de fitase e a porcentagem de $\mathrm{P}$ e Ca nas cinzas ósseas, com ponto de maximo no nível de 880 e 879 UF respectivamente. As dietas com fitase propiciaram valores inferiores para o fósforo no plasma quando comparados com o tratamento testemunha, mas não apresentaram efeitos para análise de regressão. A utilização de 759 UF em rações à base de milho, farelo de soja e farelo de arroz desengordurado para suínos na fase de crescimento permite a eliminação das fontes tradicionais de $\mathrm{P}$.

Palavras-chave: poluição ambiental, nutrição, desempenho, fósforo, fitato
\end{abstract}

\section{INTRODUCTION}

Cereals ordinarily used in swine feeds have adequate contents of total phosphorus: $0.20 \%$ for corn, $0.59 \%$ for soybean bran, $0.94 \%$ for wheat bran, $1.61 \%$ for whole rice bran (Rostagno et al., 2000) and 2.13\% for defatted rice bran (EMBRAPA, 1991). However, most of the phosphorus from plants is complexed with other minerals $(\mathrm{Ca}, \mathrm{Fe}, \mathrm{Cu}, \mathrm{Zn}, \mathrm{Mn}$ and $\mathrm{Mg}$ ) in phytate molecules, such as inositol hexaphosphate (Lehninger, 1994), and only about 20 to $25 \%$ are available to monogastric animals, (National Research Council-NRC, 1998) which do not synthesize the phytase enzyme, a substance capable of catabolizing phytate, releasing phosphorus and other minerals for animals metabolism (Cromwell, 1991). In addition to improving phosphorus availability, this enzyme also turns calcium, magnesium, copper, iron and zinc available (Adeola et al., 1995).

Phosphorus represents about 20 to $50 \%$ of the total expenses with minerals and vitamins in swine feeds (Lopes, 1998). When rations are formulated for these animals, it is necessary to add inorganic phosphorus to meet 
their nutritional requirements. As a consequence, part of the phosphorus is absorbed and another part is excreted by feces, increasing environmental pollution and reducing the cost-benefit of feeds (Ludke et al., 2000). Contamination hampers mainly water springs, triggering the eutrophication process resulting from algae growth, increasing the competition for oxygen between algae and aquatic animals (Cromwell et al., 1993).

In spite of being a very important activity from an economical and social stand point, pig breeding is considered a polluting activity by some environmental agencies (Perdomo \& Lima, 1998). There have been few studies in Brazil concerning the impact of swine excretion on soils, agriculture and environment, which could guide producers for the rational use of nutrients from feedstuffs (Perdomo \& Lima, 1998). Therefore, defining a system that would harmonize the use of animal waste as fertilizer, reducing the degree of environmental pollution represents a true challenge. In this respect, reports dealing with the use of the phytase enzyme have focused on the concern of nutritionists with regard to reducing or eliminating the inorganic phosphorus sources in swine feeds formulated with corn and soybean bran, since evidence has been found that phosphorus excretion in the feces can be reduced by about $50 \%$ with the use of phytase (Cromwell et al., 1995b).

Defatted rice bran is a low-energy byproduct from the extraction of edible oil from whole rice bran with crude protein content higher than corn, and good amino acids balance (EMBRAPA, 1991). It is also found in the market by lower prices, and its use allows reducing the final cost of feeds. Research work developed with this byproduct shows that it is possible to use about $40 \%$ of defatted rice bran in swine feeds without hurting animal performance and carcass quality (Borin Jr. et al., 1988). The use of low phytase enzyme levels added to swine feedstuffs containing corn, soybean bran and defatted rice bran is feasible from a metabolic standpoint. However, it is necessary to observe the response of animals in terms of performance and carcass traits (Moreira et al., 2000).

The effect of increasing dietary levels of the phytase enzyme on performance parameters of swine fed diets formulated with corn, soybean bran and defatted rice bran, without inorganic phosphorus sources was studied. Results were compared with a control diet containing dicalcium phosphate without the presence of the phytase enzyme.

\section{MATERIAL AND METHODS}

The study was carried out in Piracicaba, SP, using 60 half-breed animals with initial and final weights of $29.61 \pm 1.30$ and $61.13 \pm 2.70 \mathrm{~kg}$, respectively. Experimental design consisted of random blocks, with five treatments and six replicates; experimental units comprised two animals, housed in stalls with semi-automatic feeders and nipple drinkers. Treatments consisted of a standard feed containing corn, soybean bran, defatted rice bran (DRB) and vitamin and mineral mix; the control diet was supplemented with dicalcium phosphate, with no phytase enzyme and with $0.27 \%$ of available phosphorus. The other treatments, T-1, T-2, T-3 and T-4, consisted of the standard diet, with $0.17 \%$ of available phosphorus, added of increasing levels of phytase at 253; 759; 1,265 and 1,748 PU (Phytase Units $\mathrm{kg}^{-1}$ feed), corresponding respectively, to 0.011 ; 0.033; 0.055 and $0.076 \%$ supplementation of feed.

Experimental diets were isoproteic, isocaloric, isocalcic and isolysinic, formulated to meet the requirements of the swine according to Rostagno et al. (1983) and NRC (1998), except in relation to phosphorus. The available $\mathrm{P}$ in the control feed was calculated according to Gomes et al. (1989). The chemical composition of ingredients in the feeds is presented in Table 1 and the compositions of the growth feeds are shown in Table 2.

Table 1 - Chemical composition of ingredients in the feeds.

\begin{tabular}{|c|c|c|c|c|c|}
\hline \multirow[t]{2}{*}{ Nutrient } & \multicolumn{5}{|c|}{ Ingredient } \\
\hline & Corn & Soybean bran & Defatted rice bran & Dicalcium phosphate & Lime \\
\hline & $-\ldots-n$ & - & $-\ldots \%$ & -- & -1 \\
\hline Crude protein ${ }^{1}$ & 9.53 & 46.60 & 20.02 & - & - \\
\hline Ether extract ${ }^{1}$ & 6.97 & 3.32 & 3.87 & - & - \\
\hline Crude fiber ${ }^{1}$ & 4.78 & 8.18 & 10.73 & - & - \\
\hline Total $\mathrm{P}^{1}$ & 0.33 & 0.76 & 2.33 & 18.322 & - \\
\hline $\mathrm{Ca}^{2}$ & 0.02 & 0.36 & 0.11 & 24.352 & 37.32 \\
\hline $\mathrm{DE}^{2}, \mathrm{kcal} \mathrm{kg}^{-1}$ & 3,493 & 3,378 & 2,424 & - & - \\
\hline Lysine $^{2}$ & 0.23 & 2.87 & 0.62 & - & - \\
\hline Methionine $^{2}$ & 0.17 & 0.65 & 0.29 & - & - \\
\hline Threonine $^{2}$ & 0.34 & 1.78 & 0.56 & - & - \\
\hline Tryptophan ${ }^{2}$ & 0.08 & 0.67 & 0.16 & - & - \\
\hline
\end{tabular}


Table 2 - Percentage composition of growth feeds

\begin{tabular}{|c|c|c|c|c|c|}
\hline \multirow{2}{*}{ Ingredient } & \multicolumn{5}{|c|}{ Treatment } \\
\hline & Control & $\mathrm{T}-1$ & $\mathrm{~T}-2$ & $\mathrm{~T}-3$ & $\mathrm{~T}-4$ \\
\hline \multicolumn{6}{|c|}{$\begin{array}{c}--1- \\
-\end{array}$} \\
\hline Corn & 61.81 & 61.88 & 61.88 & 61.88 & 61.88 \\
\hline Defatted rice bran & 17.19 & 17.19 & 17.19 & 17.19 & 17.19 \\
\hline Vegetable oil & 1.60 & 1.60 & 1.60 & 1.60 & 1.60 \\
\hline Soybean bran & 17.00 & 17.00 & 17.00 & 17.00 & 17.00 \\
\hline Dicalcium phosphate & 0.55 & 0.00 & 0.00 & 0.00 & 0.00 \\
\hline Lime & 1.00 & 1.40 & 1.40 & 1.40 & 1.40 \\
\hline Salt & 0.35 & 0.35 & 0.35 & 0.35 & 0.35 \\
\hline Vitamin premix ${ }^{\mathrm{a}}$ & 0.40 & 0.40 & 0.40 & 0.40 & 0.40 \\
\hline Mineral premix ${ }^{b}$ & 0.10 & 0.10 & 0.10 & 0.10 & 0.10 \\
\hline Phytase enzyme & 0.000 & 0.011 & 0.033 & 0.055 & 0.076 \\
\hline \multicolumn{6}{|l|}{ Calculated values: } \\
\hline Phytase, PU kg ${ }^{-1}$ feed & 0 & 253 & 759 & 1,265 & 1,748 \\
\hline Digestible energy, $\mathrm{kcal} \mathrm{kg}^{-1}$ & 3,277 & 3,279 & 3,279 & 3,279 & 3,279 \\
\hline Crude protein & 17.26 & 17.30 & 17.30 & 17.30 & 17.30 \\
\hline Lysine & 0.74 & 0.74 & 0.74 & 0.74 & 0.74 \\
\hline Tryptophan & 0.19 & 0.19 & 0.19 & 0.19 & 0.19 \\
\hline Threonine & 0.61 & 0.61 & 0.61 & 0.61 & 0.61 \\
\hline Methionine & 0.26 & 0.27 & 0.27 & 0.27 & 0.27 \\
\hline Calcium & 0.61 & 0.61 & 0.61 & 0.61 & 0.61 \\
\hline Total phosphorus & 0.84 & 0.74 & 0.74 & 0.74 & 0.74 \\
\hline Available phosphorus & 0.27 & 0.17 & 0.17 & 0.17 & 0.17 \\
\hline Fiber & 6.19 & 6.21 & 6.21 & 6.21 & 6.21 \\
\hline Sodium & 0.14 & 0.14 & 0.14 & 0.14 & 0.14 \\
\hline
\end{tabular}

The phytase enzyme (Allzyme phytase) utilized in the experiment was produced from fungi of the $A s$ pergillus niger group, also containing cellulase, protease, xylanase and acid phosphatase, with a declared activity of 2,300 phytase units per gram $\left(\mathrm{PU} \mathrm{g}^{-1}\right)$. The phytase unit, which represents the amount of enzyme that releases $1 \mathrm{mmol}$ inorganic phosphorus from sodium phytate in one minute, under standard conditions, was determined in a sodium-phytate substrate at $37^{\circ} \mathrm{C}$ and $\mathrm{pH}$ 5.5. The manufacturer recommendation is to use 500 $\mathrm{g}$ of the product per ton of feed, corresponding to 1,150 $\mathrm{PU} \mathrm{kg}{ }^{-1}$ feed.

Water and feed were offered to animals without restriction, and feeds and animals were weighed every 14 days. Performance data for daily feed intake (DFI), food conversion efficiency (FC) and daily weight gain (DWG) were obtained according to feed intake and total weight gain. At the end of the experimental period, blood samples were collected to evaluate phosphorus and cal- cium content in the plasma; animals were slaughtered and the $3^{\text {rd }}$ and $4^{\text {th }}$ metatarsal bones were collected in order to determine bone calcium and phosphorus concentrations. The blood samples were centrifuged for $10 \mathrm{~min}$ utes at 3,000 rpm and the plasma was separated.

Bromatological analyses of the diets were performed according to AOAC (1980). The method of Fiske \& Subbarow (1925) was utilized for plasma P determination, while calcium was determined by atomic absorption spectrophotometry (Zagatto et al., 1979).

Bones were cleaned and degreased in a "Soxhlet" extractor. To calculate ash contents, samples were preburned on a hot plate, with the addition of nitric acid $\left(\mathrm{HNO}_{3} 50 \%\right)$, and then burned in a muffle at $550^{\circ} \mathrm{C}$. Ash was digested with $10 \mathrm{~mL}$ of HCL $10 \%$ and filtered a 25 $\mathrm{mL}$ volumetric flask through phosphorus-free filter paper (blue stripe, $\varnothing=8 \mathrm{~cm}$ ), and the percentage of phosphorus calculated. Calcium was determined by atomic absorption spectrometry (Zagatto et al., 1979). 
The variables: daily feed intake (DFI), daily weight gain (DWG), food conversion efficiency (FC), plasma calcium $\left(\mathrm{Ca}_{\text {plasma }}\right)$, plasma phosphorus $\left(\mathrm{P}_{\text {plasma }}\right)$, bone ash $\left(\mathrm{BONE}_{\text {ash }}\right)$, phosphorus percentage in bone ash $\left(\mathrm{PP}_{\text {ash }}\right)$, calcium percentage in bone ash $\left(\mathrm{CaP}_{\text {ash }}\right)$, bone calcium and phosphorus ratio ( $\left.\mathrm{RCa}: \mathrm{P}_{\text {bone }}\right)$ and plasma calcium and phosphorus ratio ( $\mathrm{RCa}: \mathrm{P}_{\text {plasma }}$ ) were submitted to analysis of variance and regression analysis (SAS, 1991) and related to the phytase enzyme levels. Dunnett test and analysis of variance (SAS, 1991) were used for the comparison of means between the control feed and the other treatments.

\section{RESULTS AND DISCUSSION}

Phytase levels did not affect the variables DFI, DWG and FC $(P>0.05)$ (Table 3$)$. The values obtained for these variables did not differ $(P>0.05)$ from those in the control diet, supplemented with dicalcium phosphate. The phytase enzyme released phosphorus from plant-derived ingredients at amounts which did not compromise the performance of growing swines.

Calcium and phosphorus levels can vary considerably in the diets without affecting the performance of swine Libal et al. (1969). Gomes et al. (1985) did not observe effects as well for the same variables, in a study that sought alternative sources of phosphorus for growing swine. The phosphorus requirements to maximize performance of animals is lower than the level required to maximize bone development (Koch et al., 1984).

In a research on effects of increasing levels of phytase $(750,1,050,1,250$ and 1,350 PU) on weaned shoats, in which feeds containing corn and soybean bran were utilized, Lei et al. (1993) did not detect effects for variables DFI, DWG and FC. Ludke et al. (2000) evaluated the use of $30 \%$ defatted rice bran in feeds mainly containing corn and soybean bran, without inorganic phosphorus and with increasing levels of phytase $(0,750$ and 1,000 PU) for growing swine, and again did not observe effects for the same variables.

However, Zhang et al. (2000), working with phytase produced from genetically modified canola seeds (Phytaseed) and microbial phytase (Natuphos) at 250, 500 and 2,500 PU supplementation levels, verified that there was a linear effect for DWG, with a difference of $6.7 \%$ between the 250 and the 2,500 PU levels. While testing phytase produced from yeast at the $0,1,000,2,000$ and 4,000 PU levels, Matsui et al. (2000) also verified a positive linear effect on DWG, observing $0.9 \%$ difference between the levels of 1,000 and 2,000 PU. These results are different from those obtained in the present work. However, the type of enzyme and levels were different. Therefore, the use of phytase in swine feeds arises as an alternative to replace inorganic phosphorus sources. However, the high cost of this enzyme is the main limiting factor. Therefore, the utilization of a product with greater or less activity will depend on how much it could overburden the cost of diets.

There was no effect $(P>0.05)$ of phytase enzyme content on the concentrations of plasma $\mathrm{Ca}$ and $\mathrm{P}$. However, when compared to the control feed, plasma $\mathrm{P}$ at different phytase levels presented a smaller value $(P<0.05)$. This result occurred because the control treatment contained more total phosphorus than treatments $\mathrm{T}-1, \mathrm{~T}-2$, $\mathrm{T}-3$ and $\mathrm{T}-4$, demonstrating that even though the physiological system is quite efficient in controlling the concentration of minerals in the plasma, the excess can be detected. The concentration of plasmatic phosphorus ranges between 8 and $10 \mathrm{mg} \mathrm{dL}^{-1}$ (Ullrey et al., 1967; Gurtler et al., 1984). The metabolism of P is directly related to calcium metabolism, and their variation in the plasma is small because of its efficient physiological mechanism, which involves parathyroid hormones (PTH), calcitonin and vitamin D (Ganong, 1977; DeLuca, 1979).

Table 3 - Effects of increasing levels of phytase enzyme on performance variables.

\begin{tabular}{|c|c|c|c|c|c|c|}
\hline \multirow{2}{*}{ Variable } & \multicolumn{6}{|c|}{ Treatment } \\
\hline & Control & $\mathrm{T}-1$ & $\mathrm{~T}-2$ & $\mathrm{~T}-3$ & $\mathrm{~T}-4$ & $\mathrm{CV}, \%$ \\
\hline Feed intake $\left(\mathrm{kg} \mathrm{day}^{-1}\right)$ & $2.11 \mathrm{a}$ & $1.89 \mathrm{a}$ & $1.99 \mathrm{a}$ & $1.93 \mathrm{a}$ & $1.99 \mathrm{a}$ & 10.95 \\
\hline Weight gain $\left(\mathrm{g}\right.$ day $\left.^{1}\right)$ & 828 a & 746 a & 780 a & 748 a & $0.768 \mathrm{a}$ & 11.83 \\
\hline Food conversion & $2.56 \mathrm{a}$ & $2.56 \mathrm{a}$ & $2.55 \mathrm{a}$ & $2.58 \mathrm{a}$ & $2.59 \mathrm{a}$ & 2.92 \\
\hline Plasma calcium (mg \%) & $13.27 \mathrm{a}$ & $13.14 \mathrm{a}$ & $14.22 \mathrm{a}$ & $13.30 \mathrm{a}$ & $13.33 \mathrm{a}$ & 8.77 \\
\hline Plasma phosphorus (mg \%) & $9.61 \mathrm{a}$ & $7.65 \mathrm{~b}$ & $8.22 \mathrm{~b}$ & $7.33 \mathrm{~b}$ & $8.23 \mathrm{~b}$ & 9.80 \\
\hline Bone ash $\left(\mathrm{g} \mathrm{kg}^{-1} \mathrm{DM}\right)$ & $542.57 \mathrm{a}$ & $560.36 \mathrm{a}$ & $572.48 \mathrm{a}$ & $565.15 \mathrm{a}$ & $560.97 \mathrm{a}$ & 3.55 \\
\hline Percentage of phosphorus in bone ash* & $16.60 \mathrm{a}$ & $15.66 \mathrm{a}$ & $16.33 \mathrm{a}$ & $17.90 \mathrm{a}$ & $13.78 \mathrm{a}$ & 3.55 \\
\hline Percentage of calcium in bone ash* & $33.13 \mathrm{a}$ & $31.94 \mathrm{a}$ & $33.69 \mathrm{a}$ & $33.66 \mathrm{a}$ & $28.27 \mathrm{a}$ & 13.02 \\
\hline Bone calcium and phosphorus ratio & $2.00 \mathrm{a}$ & $2.06 \mathrm{a}$ & $2.08 \mathrm{a}$ & $1.91 \mathrm{a}$ & $2.05 \mathrm{a}$ & 11.75 \\
\hline Plasma calcium and phosphorus ratio & 1.38 & 1.73 & 1.73 & 1.72 & 1.62 & 16.70 \\
\hline
\end{tabular}

*Quadratic relation $(P<0.05)$.

Means with a common letter in the same row do not differ from the control treatment by Dunnett test. 
The relation between phytase enzyme levels and bone ash did not have an effect $(P>0.05)$ for regression analysis. No effects were observed as well when treatments means where phytase was used were compared to the control treatment.

A quadratic relation was verified between the levels of phytase in the feed $(\mathrm{X})$ and the percentage of phosphorus in bone ash $(\mathrm{Y})$, where $\mathrm{Y}=13.402+0.0088 \mathrm{X}-$ $5 \mathrm{E}-06 \mathrm{X}^{2} ; \mathrm{R}^{2}=0.74$, with a point of maximum at the 880 $\mathrm{PU} / \mathrm{kg}$ feed level (Figure 1). The results for this variable are consonant with those found by Lei et al. (1993) and Cromwell et al. (1995a), who observed phytase enzyme effects up to the levels of 1,200 and 2,000 PU kg ${ }^{-1}$ feed, respectively.

Phosphorus is intensely involved in metabolic processes, participating in all reactions where energy consumption is necessary. Therefore, when the ingestion of deficient feedstuff occurs, the physiological system promotes bone phosphorus recycling, reduces excretion and increases absorption, affecting animals performance when deficiency is high. These observations are confirmed by this study, since phytase did not interfere with performance, but effects were detected in the bones. The best response was obtained at the $880 \mathrm{PU}$ level, indicating that at this level the enzyme made available the amount of phosphorus necessary for the development of the growing swine.

There was a quadratic relation between the increasing levels of phytase enzyme (X) and the percentage of calcium in bone ash $(\mathrm{Y})$, where $\mathrm{Y}=29.102+$ $0.0123 \mathrm{X}-7 \mathrm{E}-06 \mathrm{X}^{2} ; \mathrm{R}^{2}=0.97$, with a point of maximum at the 879 PU level (Figure 2), showing the efficiency of phytase in making both minerals available. These results differ from those obtained by Ludke et al. (2000), who worked with the Nathuphos ${ }^{\circledR}$ enzyme at 0 , 750 and 1,000 PU levels in feeds containing 30\% defatted rice bran, and did not observe effects for variables bone $\mathrm{Ca}$ and $\mathrm{P}$. The calcium and phosphorus metabolisms are strictly related. Thus, as the physiological system in swine mobilized bone phosphorus, it also mobilized calcium to maintain adequate bone and plasma calcium and

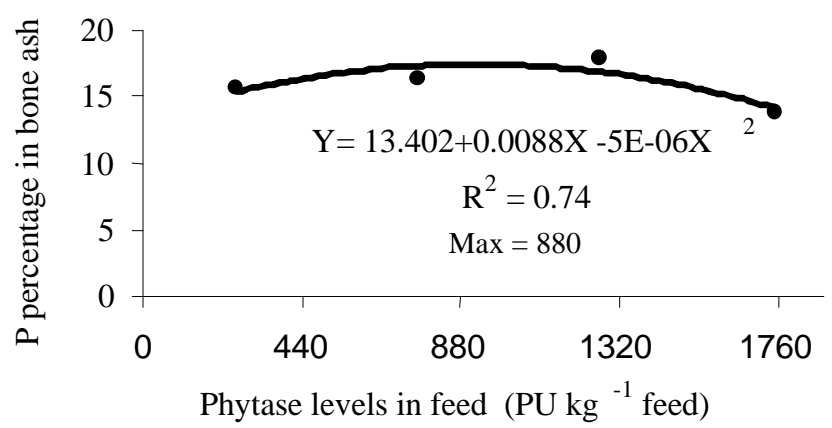

Figure 1 - Relationship between increasing phytase levels and $\mathrm{P}$ percentage in bone ash. $(P<0.05)$

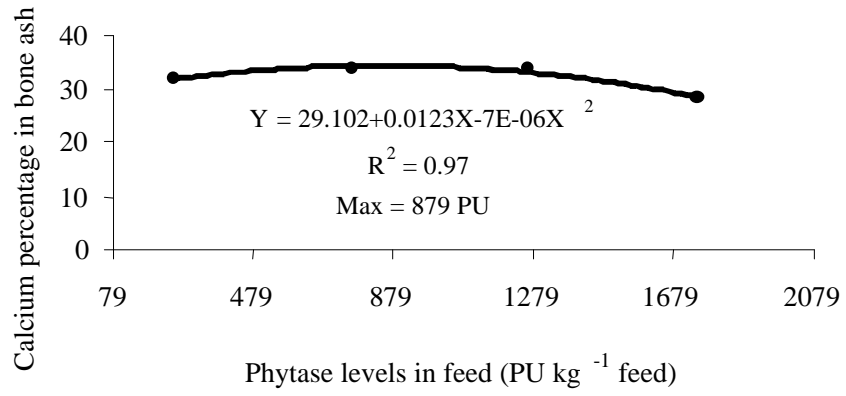

Figure 2 - Relationship between increasing phytase levels and $\mathrm{Ca}$ percentage in bone ash. $(P<0.005)$

phosphorus ratios, with the excess being eliminated endogenously and via urinary excretion, since the diets were not deficient in calcium. The maximum response determined for calcium was similar to that observed for phosphorus, and confirm these assertions.

No effects were verified $(P>0.05)$ for the relation between the phytase enzyme and the bone ash variable. The levels and ratio of $\mathrm{Ca}$ and $\mathrm{P}$ in the diets, can vary considerably without significantly influencing weight gain and food conversion efficiency of growing swine, but interfering with bone characteristics (Libal et al., 1969). These observations were confirmed by the present study.

Enzyme levels did not affect the calcium: phosphorus ratio in bones and plasma, with mean ratios of $2: 1$ and 1.70:1, respectively. The bone Ca:P ratio, bones being the place with the highest concentration of this mineral, is around 2:1 (Lopes, 1998). However, the recommended ratio for swine diets is based on the physiology of the animal itself, and is around 1.5:1, and corresponds to values found in sow milk (Peo Jr. et al., 1991). However, this experiment utilized ratios of 0.7:1.0 based on total phosphorus and 2.26:1 based on available phosphorus. When the work is based upon available phosphorus, this ratio can range on 2:1 and 3:1 (Qian et al., 1996 and NRC, 1998). Qian et al. (1996) studied the effects of increasing levels of calcium and phosphorus ratio (1.2:1, 1.6:1 and 2.0:1) on weanling pigs, by using two microbial phytase levels (700 and 1,050 PU), and did not observe effects on bone deposition; however, for DWG, DFI and FC they observed a negative linear effect, showing that phytase is more efficient when the $\mathrm{Ca}: \mathrm{P}$ ratio is smaller. The total $\mathrm{Ca}: \mathrm{P}$ ratio in feeds containing soybean bran can vary from 1:1 to $1.25: 1$ (NRC, 1998). The ratio can be less critical if excess phosphorus occurs (Prince et al., 1984, Hall et al., 1991). However, excess calcium in the diets reduces organic phosphorus bioavailability (Jongbloed et al., 1993).

The supplementation of feeds formulated with corn, soybean bran, defatted rice bran and soybean oil with 759 PU for growing swine allows the traditional phosphorus sources to be eliminated; however, the eco- 
nomic feasibility of phytase utilization should be taken into consideration. Metabolism studies should be developed to evaluate phosphorus excretion to the environment.

\section{ACKNOWLEDGEMENT}

To FAPESP for a scholarship and APTA-Centro Sul for experimental development support.

\section{REFERENCES}

ADEOLA, O.; LAWRENCE, B.V.; SUTTON, A.L.; CLINE, T.R. Phytaseinduced in mineral utilization in zinc-supplemented diets for pigs. Journal of Animal Science, v.73, p.3384-3391, 1995.

ASSOCIATION OF OFFICIAL ANALYTICAL CHEMISTS - AOAC. Official methods of analysis. 13.ed. Washington: AOAC, 1980. 1018p.

BORIN JR., H.; GAI, J.N.; SILVEIRA, J.C.G.L. Efeitos da adição de diferentes níveis de farelo de arroz desengordurado em rações para suínos nas fases de crescimento e terminação. Revista da Sociedade Brasileira de Zootecnia, v.17, p.553-563, 1988.

CROMWELL, G.L. Phytase appears to reduce phosphorus in feed, manure. Feedstuffs, v.63, p.41, 1991

CROMWELL, G.L.; STAHLY, T.S.; COFFEY, R.D.; MONEGUE, H.J.; RANDOLPH, J.H. Efficacy of phytase in improving the bioavailability of phosphorus in soybean meal and corn-soybean meal diets for pigs. Journal of Animal Science, v.71, p.1831-1840, 1993.

CROMWELL, G.L.; COFFEY, R.D.; MONEGUE, H.J.; RANDOLPH, J.H. Efficacy of low-activity, microbial phytase in improving the bioavailability of phosphorus in corn-soybean meal diets for pigs. Journal of Animal Science, v.73, p.449-456, 1995a.

CROMWELL, G.L.; COFFEY, R.D.; PARKER, G.R.; MONEGUE, H.J.; RANDOLPH, J.H. Efficacy of a recombinant-derived phytase in improving the bioavailability of phosphurus in corn-soybean meal diets for pigs. Journal of Animal Science, v.73, p.2000-2008, 1995b.

DeLUCA, H.F. The vitamin D system in the regulation of calcium and phosphorus metabolism. Nutrition Review, v.37, p.161-193, 1979.

EMPRESA BRASILEIRA DE PESQUISA AGROPECUÁRIA EMBRAPA. Tabela de composição química e valores energéticos de alimentos para suínos e aves. 3.ed. Concórdia: EMBRAPA, CNPSA, 1991. 97p

FISKE, C.H.; SUBBARROW, Y. The colorimetric determination of phosphorus. Journal of Biological Chemistry, v.66, p.375-400, 1925.

GANONG, W.F. Fisiologia médica. 3.ed. São Paulo: Atheneu, 1977. 585p.

GOMES, P.C.; BELLAVER, C.; FIALHO, E.T.; PROTAS, J.F.; GOMES, M.F.M. Fontes alternativas de fósforo na alimentação de suínos em crescimento e terminação. Revista da Sociedade Brasileira de Zootecnia, v.14, p.241-246, 1985.

GOMES, P.C.; ROSTAGNO, H.S.; PEREIRA, J.A.A.; COSTA, P.M.A.; LIMA, J.A.F. Exigência de fósforo total e disponível para suínos na fase de crescimento. Revista da Sociedade Brasileira de Zootecnia, v.18, p.232-239, 1989.

GURTLER, H.; KETZ, H.A.; KOLB, E.; SCHRODER, L.; SEIDEL, H. Fisiologia veterinária. 4.ed. Rio de Janeiro: Guanabara Koogan, 1984. $612 \mathrm{p}$.

HALL, D.D.; CROMWELL, G.L.; STAHLY, T.S. Effects of dietary calcium, phosphorus, calcium:phosphorus ratio and vitamin $\mathrm{K}$ on performance, bone strength and blood clotting status of pigs. Journal of Animal Science, v.69, p.646-655, 1991

JONGBLOED, A.W.; MROZ, Z.; KEMME, P.A.; GEERSE, C.; HONING, $Y$. The effect of dietary calcium levels on microbial phytase efficacy in growing pigs. Journal of Animal Science, v.71, p.166, 1993 Supplement 1 .

KOCH, M.E.; MAHAN, D.C.; CORLEY, J.R. An evaluation of various biological characteristic in assessing low phosphorus in take in wealing swine. Journal of Animal Science, v.59, 1546-1556, 1984.
LEHNINGER, A.L. Princípios de bioquímica. São Paulo: Sarvier, 1994 $725 \mathrm{p}$.

LEI, X.G.; KU, P.K.; MILLER, E.R.; YOKOYAMA, M.T. Supplementing corn-soybean meal diets with microbial phytase linearly improves phytase phosphorus utilization by weanling pigs. Journal of Animal Science, v.71, p.3359-3367, 1993.

LIBAL, G.W.; PEO JR., E.R.; ANDREWS, R.P.; VIPPERMAN JR., P.E. Levels of calcium and phosphorus for growing-finishing swine. Journal of Animal Science, v.28, p.331-335, 1969.

LOPES, J.B. Avaliação da absorção real e das perdas endógenas de fósforo em suínos pela técnica de diluição isotópica. Piracicaba: USP/CENA, 1998. 87p. (Tese - Doutorado)

LUDKE, M.C.M.M.; LOPEZ, J.; NICOLAIEWSKY, S. Efeito da fitase com ou sem fosfato inorgânico para suínos em crescimento. Revista Brasileira de Zootecnia, v.29, p.485-494, 2000.

MATSUI, T.; NAKAGAWA, Y.; TAMURA, A.; WATANABE, C.; FUJITA K.; NAKAJIMA, T.; YANO H. Efficacy of yeast phytase in improving phosphorus bioavailability in a corn-soybean meal-based diet for growing pigs. Journal of Animal Science, v.78, p.94-99, 2000

MOREIRA, J.A.; VITTI, D.M.S.S.; LOPES, J.B. Estudo dos efeitos da enzima fitase em rações para suínos através do radiofósforo - P-32. In: REUNIÃO ANUAL DA SOCIEDADE BRASILEIRA DE ZOOTECNIA, 37., Viçosa, 2000. Anais. Viçosa: SBZ, 2000. p.292.

NATIONAL RESEARCH COUNCIL - NRC. Nutrient requirements of swine. 10.ed. Washington: NRC, 1998. 189p.

PEO JR., E.R. Calcium, phosphorus and vitamin D in swine nutrition. In MILLER, E.R.; ULTREY, D.E.; LEWIS, A.J. Swine nutrition. Boston: Butterworth-Heinemann, 1991. p.165-182.

PERDOMO, C.C.; LIMA, G.J.M.M. Considerações sobre a questão dos dejetos e o meio ambiente. In: SOBESTIANSKY, S.; WENTZ, I.; SILVEIRA, P.R.S.; SESTI, L.A.C. Suinocultura intesiva. Concórdia: EMBRAPA, CNPSA, 1998. cap.11, p.221-235.

PRINCE, T.J.; HAY, V.W.; CROMWELL, G.L. Interactive effects of dietary calcium, phosphorus and cooper on performance and liver cooper stores pigs. Journal of Animal Science, v.58, p.356-361, 1984.

QIAN, H.; KORNEGAY, E.T.; CONNER JR., D.E. Adverse effects of wide calcium:phosphorus ratios on supplemental phytase efficacy for weanling pigs fed two dietary phosphorus levels. Journal of Animal Science, v.74, p.1288-1297, 1996.

ROSTAGNO, H.S.; SILVA, D.J.; COSTA, P.M.A.; FONSECA, J.B.; SOARES, P.R.; PEREIRA, J.A.A.; SILVA, M.A. Composição de alimentos e exigências nutricionais de aves e suínos: tabelas brasileiras. Viçosa: Imprensa Universitária-UFV, 1983. 61p.

ROSTAGNO, H.S.; ALBINO, L.F.T.; DONZELE, J.L.; GOMES, P.C. FERREIRA, A.S.; OLIVEIRA, R.F.; LOPES, D.C. Tabelas brasileiras para aves e suínos: composição de alimentos e exigências nutricionais. 1.ed. Viçosa: Imprensa Universitária, 2000. 141p.

STATISTICAL ANALYSIS SYSTEM - SAS. Applications guide. 1.ed Cary: SAS Institute Inc., 1991. 380p.

ULLREY, D.E.; MILLER, E.R.; BREMT, B.E.; BRADLEY, B.L.; HOEFER, J.A. Swine hematology from birth to madure IV serum calcium, magnesium, sodium, potassium, cooper, zinc and inorganic phosphorus. Journal of Animal Science, v.26, p.1024-1029, 1967.

ZAGATTO, E.A.G.; KRUG, F.J.; BERGAMIN FILHO, H.; JORGENSEN, S.S.; REIS, B.F. Merzing in flow injection analysis. Part 2. Determination of calcium, magnesium and potassium in plant material by flow injection atomic and flame emission spectrometry. Analytica Chimica Acta, v.104, p.279-284, 1979.

ZHANG, Z.B.; KORNEGAY, E.T.; RADCLIFFE, J.S.; WILSON, J.H. VEIT, H.P. Comparison of phytase from genetically engineered aspercillus and canola in weanling pig diets. Journal of Animal Science, v.78, p. $2868-2878,2000$.

Received September 19, 2002

Accepted August 14, 2003 